\title{
The humpback whale off The Coast of Ecuador, population parameters and behavior
}

\author{
La ballena jorobada en la costa de Ecuador, parámetros poblacionales y comportamiento \\ Fernando Félix and Ben Haase \\ Fundación Ecuatoriana para el Estudio de Mamíferos Marinos (FEMM). P.O. Box 09-01-11905. Guayaquil, Ecuador
fefelix90@hotmail.com
}

Resumen.- Entre 1991 y 1997 la existencia de ballenas jorobadas (Megaptera novaeangliae) del Pacífico Sudeste fue estudiada en la parte central de Ecuador (01²4’S, 8055’W) durante su temporada de reproducción (junio-septiembre). Para este propósito se realizaron viajes en embarcaciones turísticas desde dos diferentes sitios: Puerto López y Puerto Cayo. Se evaluaron algunos parámetros poblacionales tales como distribución, estructura grupal, tamaño de la población, tasa de nacimientos y comportamiento. Las primeras ballenas arribaron a finales de mayo, alcanzaron su máximo poblacional en julio y a finales de septiembre la mayoría ya hubo dejado el área. A lo largo de la ruta de Puerto López los grupos fueron significativamente más grandes $(\mathrm{P}<0.01)$ pero las ballenas fueron significativamente menos abundantes que en la ruta de Puerto Cayo $(\mathrm{P}<0.01)$. La posición de los avistamientos con GPS mostró que las ballenas presentaron una distribución agrupada con concentraciones en sitios específicos a lo largo de ambas rutas. El análisis de la composición de los grupos sugiere la presencia de un tipo de segregación por clases de edad y sexo dentro del área de estudio. Alrededor de sitios como isla de La Plata y Bajo de Cantagallo los grupos estuvieron compuestos principalmente por adultos y subadultos. En contraste, cerca de Puerto Cayo los grupos estuvieron compuestos principalmente por madres con crías e individuos solitarios. Los grupos cambiaron al menos un miembro cada 257 minutos en promedio, pero no se notó ningún cambio cuando una madre con cría estuvo presente. Las crías fueron registradas principalmente a partir de la segunda quincena de agosto y mostraron preferencia por sitios de $20 \mathrm{~m}$ o menos de profundidad. La tasa cruda de nacimientos obtenida (0.039) se considera que está subestimada. La baja tasa de reavistamientos de individuos fotoidentificados indica tanto un bajo nivel de residencia como de filopatria. El tamaño de la población fue estimado en 1,922 ballenas (I.C. 95\% 77-3,367) en 1996.

Palabras clave: Ballena jorobada, stock del Pacífico sudeste, parámetros poblacionales, Ecuador, Sudamérica.

\begin{abstract}
Between 1991 and 1997 the southeastern Pacific humpback whale (Megaptera novaeangliae) stock was studied off the central part of Ecuador (0124'S, $80^{\circ} 55^{\prime} \mathrm{W}$ ) during the breeding season (June-September). For this purpose, surveys were carried out onboard whale-watching boats at two different sites: Puerto López and Puerto Cayo. Some population parameters such as distribution, group structure, population size, calving rate and behavior were evaluated. The first whales arrived by the end of May, they peaked in July and most of them had left the area by the end of September. Along the Puerto López route, groups were significantly larger $(\mathrm{P}<0.01)$ but whales were significantly less abundant $(\mathrm{P}<0.01)$ than Puerto Cayo's. GPS-positioned sightings showed that whales presented a clumped distribution with concentrations at specific sites along both surveyed routes. Analyses of group composition suggest a type of age/sex-class segregation inside the study area. Around sites such as La Plata Island and the Bajo de Cantagallo groups were composed mainly of adult and subadult animals. In contrast, nearby Puerto Cayo groups were composed mainly of mothers with calves and solitary individuals. Groups changed at least one member every 257 minutes on the average, but no change in membership was noticed when a mother-calf pair was present. Most calves were recorded from the second half of August onward and showed a preference for shallow waters with $20 \mathrm{~m}$ or less in depth. The crude birth rate average obtained (0.039) is considered underestimated. A low resighting rate of photo-identified individuals indicates both a low residence level and a poor degree of fidelity to the study site. The size of the stock was estimated in 1996 to be 1,922 whales (95\% C.I. 77-3,367).

Keywords: Humpback whale, southeastern Pacific stock, population parameters, Ecuador, South America.
\end{abstract}

\section{Introduction}

The humpback whale Megaptera novaeangliae (Borowski 1781), is a cosmopolitan species that annually carry out long migrations between their breeding grounds located in the tropics and their feeding grounds located in polar waters (Leatherwood and
Reeves 1983, Jefferson et al. 1993). Humpbacks were severely exploited because their natural tendency to concentrate near islands and coastal areas, where they were easy prey for whalers. The species received full protection by the International Whaling Commission (IWC) in the south hemisphere since 1966; then it was estimated that only hundred of animals remained in each 
stock (Chapman 1974). After all these years of complete protection most of the stocks are recovering but the species is still considered as vulnerable (Reeves and Leatherwood 1994).

The southeastern Pacific humpback whale stock occurs along the west coast of South America. Their breeding grounds, located off the coasts of Ecuador and Colombia, were known a long time ago by whalers who had operated in the area since the XVIII century (Townsend 1935, Clarke 1962, 1992). Besides the Antarctic waters where the main takes were carried out (Chapman 1974), the stock was exploited during its annual migration from whaling stations installed in Peru and Chile and during sporadic pelagic campaigns of factory ships that visited the area on the first half of the XX century (Chiriboga 1972, Clarke 1962, 1980, 1992, Aguayo 1974, Ramírez 1988).

Whaling records provided valuable information about the southeastern Pacific humpback whale stock in aspects related to their biology, distribution and catches. Until recently, this was the unique information available from these whales. By the mid 80's, the first efforts to study humpback whales using benign methods begun on the west coast of South America at Gorgona island $\left(3^{\circ} \mathrm{N}\right)$, Colombia (Flórez 1991, Ojeda and Hurtado, 1992, Capella and Flórez 1993) and since the early 90s off the central coast of Ecuador (1¹5's) (Haase 1990, Félix and Haase 1996, 1997, 1998, Scheidat et al. 2000). The use of natural marks for individual recognition has allowed scientists of the region to observe the same individuals at different stages in their migratory route, providing a better understanding on whale movements and distribution along the southeastern Pacific (Flórez et al. 1998). It has established also the link between humpback whales breeding off Ecuador and Colombia with animals feeding around Antarctic peninsula (Stone et al. 1990, Muñoz et al. $1998^{1}$ ). Genetic studies from skin samples have revealed interesting information about the stock identity and intraspecific heterogeneity (Caballero et al. 2000). However, other aspects related to whale sociality, population structure and group dynamic are still poorly known.

In this article we present the results of a 7-year study on humpback whales conducted off the coast of Ecuador. The aim of the study was to obtain basic information on population parameters of this stock

\footnotetext{
${ }^{1}$ Muñoz E, F Félix, L Flórez, B Haase, S Katona, L Lodi, M McOsker, K Robertson, P Stevick \& S. Siciliano. 1998. Migrations of individually identified humpback whales (Megaptera novaeangliae) between the Antarctic peninsula and South America. The World Marine Mammal Science Conference (WMMSC). Monaco 20-24 January, 1998. (Abstract).
}

for future management. The results are compared with similar studies made in Colombia with the same stock and with other better known populations from the northern Hemisphere.

\section{The Study Area}

The study area is located in the central part of Ecuador $\left(01^{\circ} 24^{\prime} \mathrm{S}, 80^{\circ} 55^{\prime} \mathrm{W}\right)$ between the coastal villages of Puerto López, Puerto Cayo and La Plata Island (Figure 1). It covers around $800 \mathrm{~km}^{2}$ of sea with a maximum water depth of $50 \mathrm{~m}$. The area includes most of the marine zone of the Machalilla National Park, which extends 2 miles off shore from Puerto Cayo to Salango (30km south) and 2 miles around La Plata Island. The zone is characterized by a subtropical climate with two well-defined seasons, a dry and cold (June-November) and a warm and rainy season (December-April). The climate, pluviosity and water temperature are strongly related to the ocean-atmospheric interaction of north and south trade winds with a complex current system of 2 surface (west) and 2 subsurface countercurrents and one submarine current that flow in opposite direction (east), called the equatorial front (Espinoza 1996). Another northward cold water current bordering the South America coast from Chile to Ecuador, the Humboldt current, meets the equatorial front off Ecuador and deflects towards the west.

\section{Materials and Methods}

The information presented in this article was obtained during the period 1991-1997 onboard whale-watching boats that regularly operated on the central part of Ecuador. Trips lasted 3-8 hours and took place on weekends between June and September, although not in a systematic way. At least 6 different boats were used for the purpose, they were similar in capacity (10-20 persons), size (8-10m length) and high (12m). Boats followed two specific routes: 1) Puerto López-La Plata Island-Puerto López (84km) and 2) Puerto Cayo-Bajo de Cantagallo-Puerto Cayo (38km). Despite both routes were just $15 \mathrm{~km}$ apart on the average, they differed in depth and distance to shore; the Puerto López route went along the 50m isobath, moving away from shore, whilst the northernmost Puerto Cayo route went in water less than $20 \mathrm{~m}$ depth in a parallel course to shore. This difference was due to the particular geography of the study area, which is located inside a wide cove (Figure 1). 


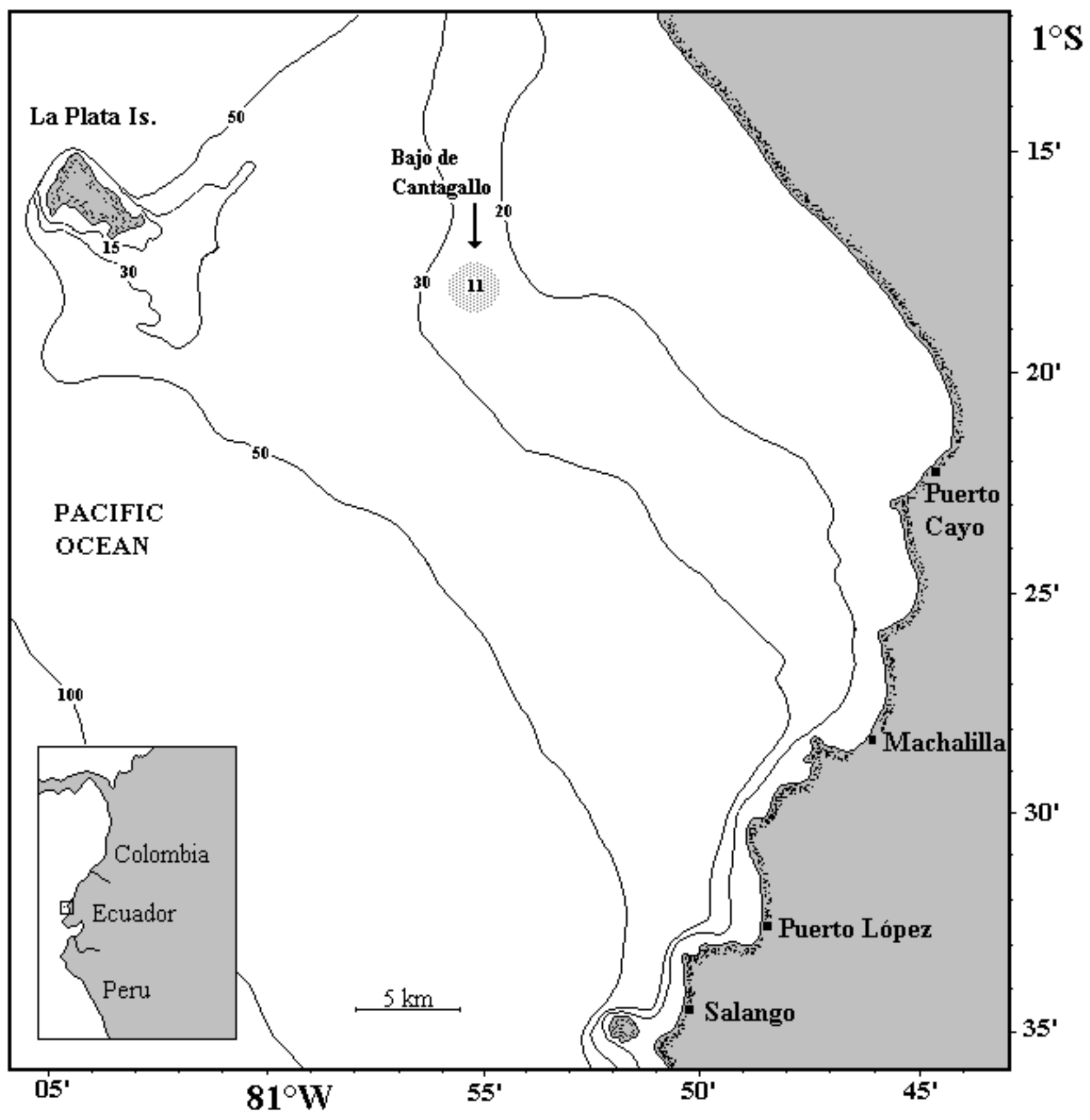

Figure 1

The study area.

Area de estudio.

Once the whales were located, they were approached slowly to around $50-100 \mathrm{~m}$. Information about the number of animals, group composition and behavior was recorded during the sightings. The behavior of the whales was evaluated taking as a basis the presence and frequency of eleven specific surface displays (see Table
4). Exact positions of the animals were obtained with a portable GPS (only in 1996 and 1997) and later marked on a navigation chart to show whale distribution. The observation period lasted 2-160 minutes ( $X=33.4)$ depending on the type of group, behavior and available time. Whales were photographed using $35 \mathrm{~mm}$ cameras 
equipped with zoom lenses $80-300 \mathrm{~mm}$ and $500 \mathrm{~mm}$ and slide and color films ISO 100-200. Photographs of the ventral side of the flukes were used for individual identification through their unique coloration pattern (see Katona et al. 1979). Every whale was labeled with a sequential number and photos stored in a catalogue curated at the Fundación Ecuatoriana para el Estudio de Mamíferos Marinos in Guayaquil, Ecuador.

A "group" was considered to be formed by whales within approximately $100 \mathrm{~m}$, headed in the same direction and in general showed the same behaviour. Although on several occasions more whales were observed nearby (200-3000m away), they were not considered as part of the same basic group, unless they obviously interacted with the initially observed group (Félix and Haase 1998). Only those groups actively followed by the boat were considered for the statistics. The number of records used for every particular analysis is expressly indicated. To determine the composition of the groups a subjective criterion based in the relative size of the animals was used. We distinguish three classes of animals eye-measured at field: adults (big size $>10 \mathrm{~m}$ ), subadults (medium size 6-10m) and calves (small size $<6 \mathrm{~m}$ and always accompanied by a bigger whale, presumably the mother). Based in such criteria, groups were included in one of the following categories: $A=$ all adults, $\mathrm{S}=$ all subadults, AS=adults with subadults, $\mathrm{MC}=$ mother with calf, $\mathrm{ME}=$ mother with calf and escort and $\mathrm{M}+=$ mother with calf and more than one escort. We are aware that males could be confused in the field with subadults because of their smaller size in respect to females, so groups formed by adult and subadults (AS) could be in fact formed only by adult animals (females and smaller males). We suggest caution interpreting these data; they are included in the article rather as a reference to indicate that body length differences among animals existed in such groups.

Population size was estimated with the animals naturally marked through Peterson's mark-recapture method modified by Bailey (Seber 1982). Working with naturally marked humpback whales fulfills most of the estimation model conditions mainly because animals are not handled during the marking process (photography), so it is expected that neither survivorship nor catchability are affected (Hammond 1986).

\section{Results}

\section{Effort Deployed}

During the study 126 trips were carried out, 89 departed from Puerto López and 37 from Puerto Cayo. A total of 635 whales were recorded in 487 hours of navigation. Table 1 shows details of the effort deployed and the amount of whales sighted, identified and resighted in every season. In the last two seasons (1996 and 1997) the effort increased considerably in respect of the first 5 years with trips departing both from Puerto López and Puerto Cayo at same time. The effort in both routes was concentrated between July and September (92\%), August being the month with the highest effort (Fig. 2). On average, the effort in the Puerto López route was 3.6 times bigger than in Puerto Cayo's. Trips from Puerto López started in June and from Puerto Cayo in July, except for a trip made in May 1996.

Table 1

Details of the effort deployed in every season between 1991 and 1997.

Detalle del esfuerzo desplegado en cada ruta entre 1991 y 1997.

\begin{tabular}{lrrrrrrrrrr}
\hline \multicolumn{1}{c}{ ITEM } & \multicolumn{4}{c}{ PUERTO LÓPEZ } & \multicolumn{5}{c}{ PUERTO CAYO } & TOTAL \\
& 19911992 & $1993^{*}$ & $1994^{*}$ & 1995 & 1996 & 1997 & 1996 & 1977 & 16 \\
\hline Total number of trips & 7 & 5 & 2 & 7 & 16 & 28 & 24 & 21 & 16 & 126 \\
Net navigation time (hours) & 30.2 & 26 & & & 108 & 150.3 & 75.5 & 44.7 & 52.4 & 487.1 \\
Total number of sightings & 17 & 6 & & & 43 & 64 & 50 & 41 & 31 & 252 \\
Total sighting time (hours) & 9.7 & 12.8 & & & 22.6 & 27.6 & 21.6 & 27 & 19.1 & 140.4 \\
Total number of whales sighted & 45 & 26 & & & 102 & 169 & 134 & 86 & 73 & 635 \\
Total number of identified whales & 9 & 13 & 1 & 14 & 31 & 45 & 40 & 34 & 32 & 219 \\
Total number of resighted whales & & & & & & & 1 & & 2 & 3 \\
\hline
\end{tabular}

* Blanks in the column are information lost. 


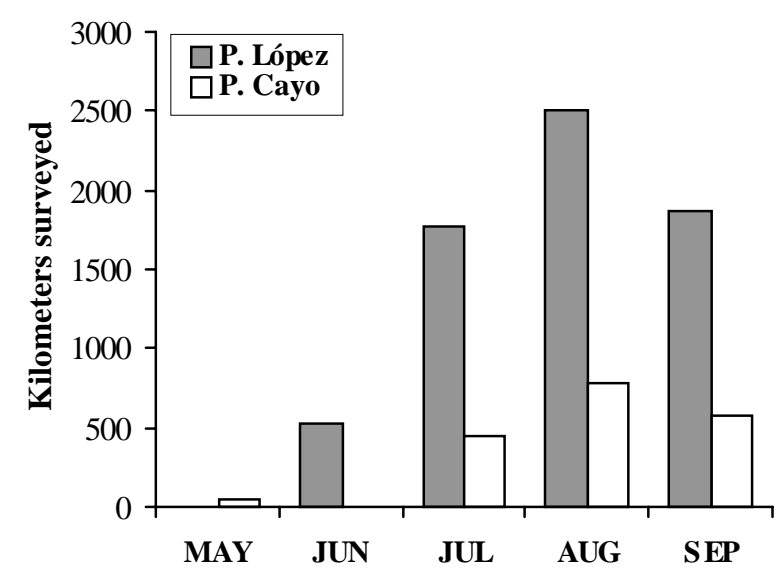

Figure 2

Monthly effort deployed during the study period in each route in the form of total kilometres surveyed. Esfuerzo mensual desplegado durante el período de estudio en cada ruta en la forma de kilómetros totales recorridos.

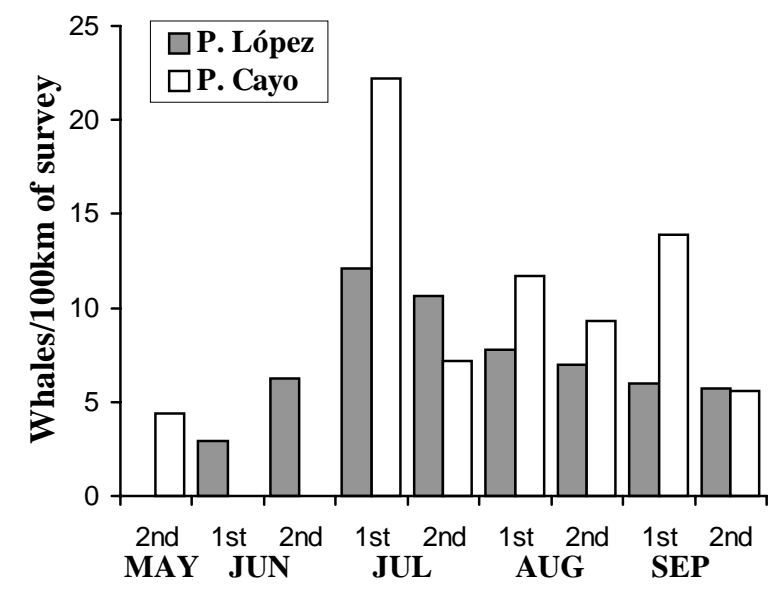

Figure 3

Average whale abundance during the breeding season in each route. Data were stratified in twoweek periods.

Abundancia promedio de ballenas durante la temporada reproductiva en cada ruta. Los datos se fueron estratificados quincenalmente.

\section{Abundance}

Along the Puerto López route whale abundance increased regularly from the first week of June and reached the peak the first mid of July with 12.1 whales per $100 \mathrm{~km}$ surveyed (Fig. 3). Then a progressive decrease toward the end of the season was noticed. At the end of September whales were approximately a half as abundant as in July. Along the Puerto Cayo route, whale abundance was more irregular than in Puerto Lopez. It also peaked the first half of July with 22.2 whales per $100 \mathrm{~km}$ surveyed, but after a decrease at the end of July, whale abundance increased again in the first week of September, only to decrease at the end of the month to similar levels found in the Puerto López route. At the end of the season, whales were 4 times less abundant than in July (Fig. 3).

Some parameters related to whale abundance in both routes are compared in Table 2. Despite the fact that the Puerto López route was 2.2 times longer than Puerto Cayo's, the average number of sightings per trip was just $13 \%$ higher. The difference was caused because along the Puerto López route whales were found, on the average, twice as far away from shore than Puerto Cayo's. This indicated that there were 29\% more whales per unit of effort along the Puerto Cayo route than Puerto López's, a difference that resulted statistically significant $\left(\mathrm{X}^{2}=11.80, \mathrm{P}<0.01\right)$.

Table 2

Sighting distances to port and whale abundance in each route.

Distancia desde puerto a los avistamientos y abundancia de ballenas en cada ruta.

\begin{tabular}{lccc}
\hline \multicolumn{1}{c}{ Item } & P. López & P. Cayo & Average \\
\hline Mean sighting distance to port $(\mathrm{km})$ & 28.5 & 14.1 & 23.1 \\
Number of sightings/trip & 2.25 & 1.95 & 2.15 \\
Number of whales/100km of survey & 7 & 9.8 & 7.6 \\
\hline
\end{tabular}

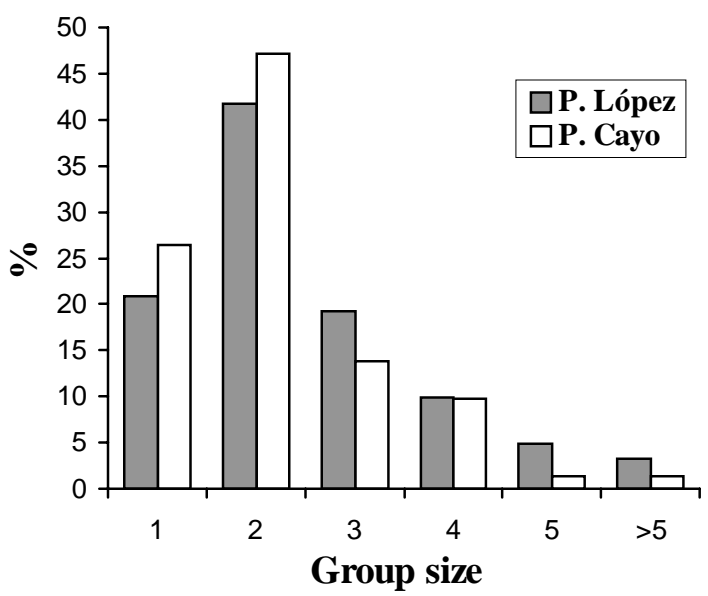

Figure 4

Groups size proportion in each route.

Tamaño de los grupos y su proporción en cada ruta. 


\section{Group size}

Humpback whales formed small groups, most of them containing 3 or less individuals ( $\mathrm{n}=212$, 83\%) (Fig. 4). In the Puerto López route a lower proportion of groups formed by 1 or 2 individuals and a higher proportion of groups formed by 3 or more individuals was found. Group size in the Puerto López route ranged between 1 and 18 individuals $(\mathrm{X}=2.64, \mathrm{SD}=1.88, \mathrm{n}=182)$, with 2 as the modal value (41.8\%). Along the Puerto Cayo route, group size ranged between 1 and 5 individuals $(\mathrm{X}=2.21, \mathrm{SD}=1.11, \mathrm{n}=72)$ with 2 the modal size (47.2\%). Mean group size was significantly different between both routes $\left(\mathrm{F}_{181,71}=3.38, \mathrm{P}<0.01\right)$.

Along the Puerto López route pairs distributed along the whole route, singles were found mainly on the first half of the route and larger groups were recorded mainly around La Plata Is. (Fig. 5). Inside the area from La Plata Is. and $10 \mathrm{~km}$ eastward, groups formed by 3 or more individuals were twice more frequent than along the rest of the route, but solitary individuals were 2 times less frequent. Group size average was significantly larger around La Plata Is. ( $\mathrm{X}=3.03$ inds./group, $\mathrm{SD}=1.81, \mathrm{n}=43$ ) than along the rest of the route $(\mathrm{X}=2.44$ inds./group, $\mathrm{SD}=1.92, \mathrm{n}=42$ ) $(z=2.088, \mathrm{P}<0.05)$. Along the Puerto Cayo route, larger groups were found east from the Bajo de Cantagallo and most of the pairs and singles were found closer to port (Fig. 5). Group size average was significantly larger around the Bajo de Cantagallo (X=2.31, $\mathrm{SD}=1.07, \mathrm{n}=29)$ than near Puerto Cayo $(X=1.81$, $\mathrm{SD}=0.85, \mathrm{n}=32)(\mathrm{z}=1.99, \mathrm{P}<0.05)$.

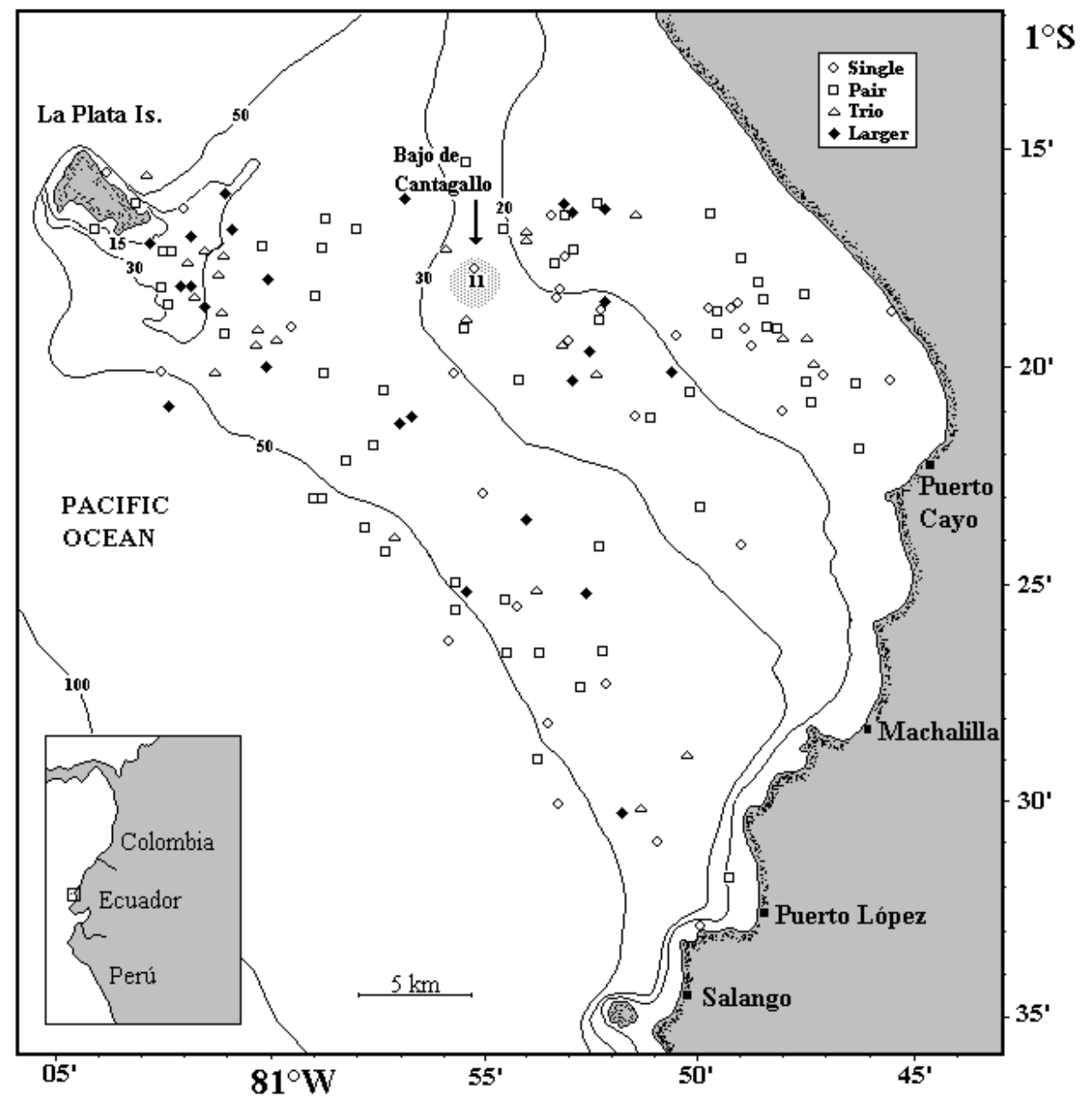

Figure 5

Group size distribution inside the study area. Dots indicate the exact location of GPS-positioned sightings with data from the seasons 1996 and 1997.

Distribución de acuerdo al tamaño de los grupos en el área de estudio. Los puntos indican la posición exacta de los avistamientos con datos de las temporadas 1996 y 1997. 


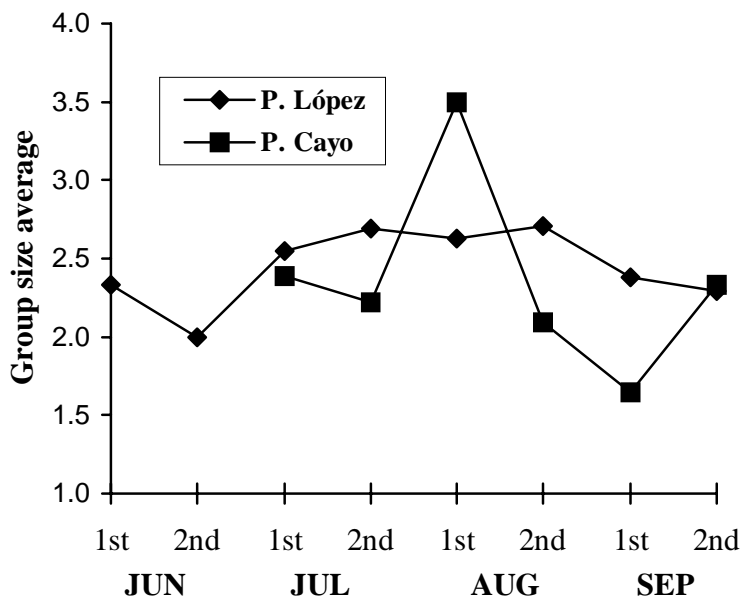

Figure 6

Average group size variation during the season in each route.

Variación del tamaño de los grupos a lo largo de la temporada en ambas rutas.

Group size average also differed during the breeding season (Fig. 6). Along the Puerto López route group size increased from June and reached the highest number between the second half of July and the second half of August. From this date onwards, group size average decreases progressively to the end of September. On the Puerto Cayo route, the curve behaves differently. Although the highest average value was reached also in August, an abrupt decrease was noticed early in September, just to rise again by the end of the month.

\section{Group composition}

Group composition was compared between both routes (Fig. 7). Most of the groups along the Puerto López route were formed by adults (A) (62.5\%) or by adult with subadults (AS) (15.6\%). The three categories that included mother with calf (MC,ME and $\mathrm{M}+$ ) reached together $15.2 \%$ and all-subadult groups (S) barely formed the $6.3 \%$ of the recorded groups. Along the Puerto Cayo route all-adult groups also predominated, but the proportion was lower than in Puerto López (43\%). The remaining classes were found in a higher proportion in this route, except for the class $\mathrm{M}+$ which had almost the same proportion in both routes. Adult with subadult groups accounted for $20 \%$ and the three categories that included mother and calf almost doubled (28.6\%) with respect to Puerto López route. All-subadult groups were similarly uncommon (8\%). However, no significant difference was found in the proportions of age and sex classes between both routes $\left(\mathrm{X}_{3}^{2}=4.47, \mathrm{P}>0.05\right)$, likely due to few frequencies in some categories.

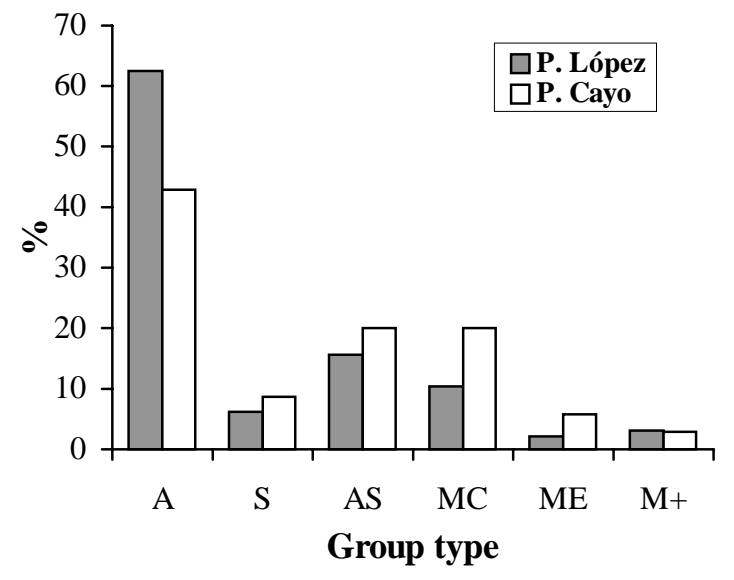

Figure 7

Group composition in each route. Only groups whose totality of members were positively identified are included ( $n=131,52 \%$ of the recorded groups).

Composición de los grupos en cada ruta. Se incluyó solo grupos cuya totalidad de miembros fueron plenamente identificados ( $\mathrm{n}=131,52 \%$ de los grupos registrados).

Age-class distribution is shown in Fig. 8. In the Puerto López route, groups of adults (A) and adults with subadults (AS) were more abundant around $\mathrm{La}$ Plata Is., whilst groups formed by mother-calf pairs and subadults were scarce along the whole route. In the Puerto Cayo route, groups of adult (A) and adult with subadults (AS) were mainly found around the Bajo de Cantagallo and mother with calf groups were more abundant near Puerto Cayo. Along both routes, mother with calf groups were found mainly in waters of $20 \mathrm{~m}$ depth or less; 12 from 16 (75\%) positioned groups showed such a distribution, difference statistically significant respect to deeper sites $\left(\mathrm{X}^{2}=4.06, \mathrm{P}<0.05\right)$. All-subadult groups, actually solitary individuals possibly just-weaned, also showed preference for shallow areas, but there were few groups recorded for statistical comparison.

\section{Group stability}

Groups were not stable for long time. In 19 of 143 groups $(13 \%)$ a change in the number of individuals was recorded during the observation period; 12 groups increased by at least one member and 7 groups decreased in number. As the sighting mean time was 33.4 minutes, this means that groups would change composition every 257 minutes on average. To show how fluid can be the association among whales we have the case of Ind. \#167, that in a 1.5 hour period formed part of three different groups. At first \#167 was observed for 48 minutes together with Ind. \#168, the pair split apart when more whales came around. Then \#167 joined 3 other whales (including \#170 and two 
unidentified animals) just to move apart 20 minutes later to join another three-member group in which its former partner \#168 and two new groupmates (\#103 and \#171) were present. The example could appear to be an extreme case, but probably shows the behavior of a male looking for a receptive female in different groups, something that we must assume to be frequent during the breeding season.
Affiliations occurred mainly in pairs (42\%) and trios (33\%) and disaffiliation occurred mainly in groups with more than 3 individuals (86\%). There were no recorded membership changes in groups containing a female with calf $(n=25)$, indicating that these type of associations were more stable. Neither were affiliations observed when solitary animals were sighted $(n=58)$.

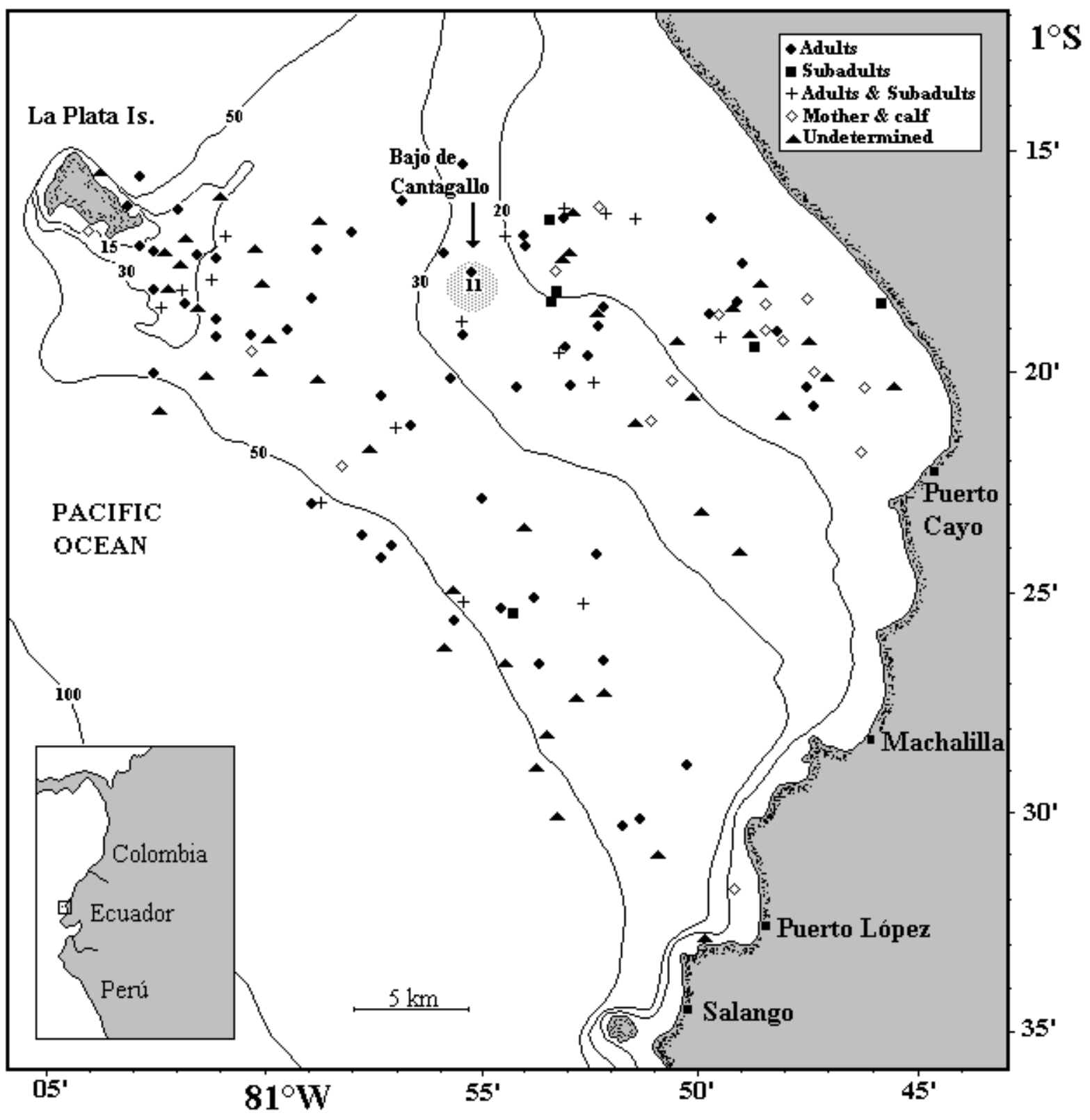

Figure 8

Age and sex-class distribution inside the study area. Dots indicate the exact location of GPS-positioned sightings with data from the seasons 1996 and 1997.

Distribución de los grupos de acuerdo a su composición por clases de edad y sexo. Los puntos indican la posición exacta de cada grupo con datos de las temporadas 1996 y 1997. 


\section{Site fidelity}

Whales showed a poor degree of fidelity to the study area; resightings were scarce not only during the season, but also on the same day. Only in 5 cases whales were recorded the same day in different observation periods. In 3 cases whales were resighted in different days during the same season: individual \#131 was sighted on $3^{\text {rd }}$ August 1996 near La Plata Is. and resighted 5 days later $8.5 \mathrm{~km}$ southeast; individual \#98 was sighted on $10^{\text {th }}$ August 1996 near Puerto López and the next day some $15 \mathrm{~km}$ northeast; and individual \#180 was sighted on $18^{\text {th }}$ June 1997 and resighted 23 days later $18 \mathrm{~km}$ north. It is unknown if all these individuals stayed in the area during the whole period between sightings or if they left and returned later.

Interannual resightings were obtained only in 1997: one whale was recorded previously in 1992 (Ind. \#13) and two in 1996 (Inds. \#89 and \#103). The last two whales showed a high level of synchrony in the date of sighting and resighting: Ind.\#89 was sighted on July $27^{\text {th }} 1996$ and resighted on July 27 $7^{\text {th }} 1997$, and Ind. \#103 was sighted on August $17^{\text {th }} 1996$ and resighted on August $24^{\text {th }} 1997$. In the case of Ind. \#13, despite 5 years between sightings, the difference was also small (August $16^{\text {th }} 1992$ and July 26 ${ }^{\text {th }} 1997$ ).

\section{Population size}

A total of 219 different whales were identified by their natural marks during the study (34\% of the total whales recorded) (Table 1). However, only data from the last two seasons (1996 and 1997) were used for estimation purposes. The size of the southeastern humpback whale stock in 1996 was estimated to be 1,922 (95\% C.I. 773,367) whales.

\section{Calving and crude birth rate}

Mothers and calves were recorded in the study area late in the season; they were more abundant from mid August onward, with only two records in June and July (Fig. 9). The class was more commonly found along the Puerto Cayo route where the crude birth rate resulted significantly higher (2.4 times) than Puerto López's $\left(\mathrm{X}^{2}=4.34, \mathrm{P}<0.05\right)$ (Table 3$)$. The average crude birth rate was 0.039 . No group recorded had more than one mother-calf pair. Most mother-calf pairs were found alone ( $n=17$ or $68 \%$ ) but in 4 cases there was one more adult and in the other 4 cases there were more than 2 adult escorts.

\section{Predation}

Although no direct evidence of predation onto the whales was observed, 14 identified animals (6.4\%) presented mutilations and bite marks from killer whales Orcinus orca (Linnaeus 1758) and probably other predator such as sharks or false killer whales
Pseudorca crassidens (Owen 1846) on their flukes. One whale had lost around $80 \%$ of the right fluke, but although the animal could not swim straight it looked healthy. The presence of these marks gives just an idea of the unsuccessful attacks, but the real impact of predation on the population is unknown. Several tourist operators have seen killer whales around La Plata Island during the breeding season and Scheidat et al. (2000) reported an attack of killer whales on humpback whales in the area. Flórez et al. (1994) also reported a similar attack near Gorgona Island, Colombia.

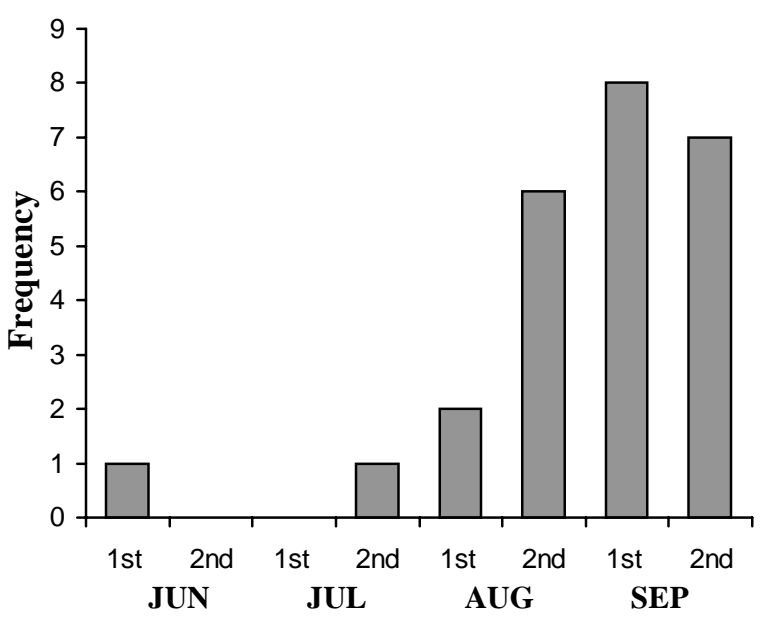

Figure 9

Frequency and periodicity of calves seen during the study $(n=25)$.

Frecuencia y periodicidad de las crías vistas durante el estudio $(n=25)$

Table 3

Number of calves observed and crude birth rate in each route.

Número de crías observadas y tasa cruda de nacimientos en cada ruta

\begin{tabular}{cccc}
\hline ITEM & P. LÓPEZ & P. CAYO & OVERALL \\
\hline Whales sighted & 476 & 159 & 635 \\
Calves sighted & 14 & 11 & 25 \\
Crude birth rate & 0.029 & 0.069 & 0.039 \\
\hline
\end{tabular}

\section{Behavior}

Humpback whales are known to be social animals that use to exhibit a wide variety of surface displays. Eleven different of such displays were quantified during the sightings (Table 4). The most frequent display was the back or side breach recorded in 38\% of the groups. Other 
displays commonly exhibited were the side swim and hitting the water surface with both the flipper (pectoral slap) and the flukes (tail slap). Less frequently were the belly breach and belly-up swimming. Uncommon displays were galloping on the surface (repeated belly bounds), raising the head and tail slashes. This last display are violent horizontal movements of the tail above the surface, possibly an annoyance display caused by competing males (see Tyack and Whitehead 1983, Darling et al. 1983) or poor boat handling. Some of the listed displays such as breaching and hitting the surface with flippers and flukes, can be occasionally repeated dozens of times.

Chasing and aggression among whales were recorded on $9.1 \%$ of the groups. During these periods, whales showed much activity and vigorous displays such as fast swimming, chasing, sudden change of direction, turns, side swimming, air bubbles exhaled through the mouth, pushing and charges. Is has been established that such groups would be males competing for access to receptive females and can be so violent as to produce even bleeding wounds (Tyack and Whitehead, 1983; Darling et al., 1983; Baker and Herman, 1984; Silber, 1986). Those groups were formed of three or more individuals $(\mathrm{X}=3.76, \mathrm{SD}=1.2 ; \mathrm{n}=23)$ and were observed mainly by mid season, especially between the end of July and the end of August, with few records at the beginning (June) or end of the season (September) (Fig. 10). Most of the records were made along the Puerto López route $(n=20$, $87 \%)$.

Whale behavior during periods of affiliation and disaffiliation was analyzed. In both cases a rise in the activity of the whales was observed (Table 4). During affiliations the more common displays recorded were: side swimming (67\%), hitting the surface with the tail (50\%) and flipper (33\%) and chasing or aggression among whales (33\%). In contrast, during disaffiliation whales displayed mainly breaching (57\%), side swimming (43\%) and tail slashes (29\%). Side swimming increased during both periods, but the rest of the displays were noticeably different in every situation. The low frequencies $(n<5)$ in most categories impeded the application of statistical test for comparison.

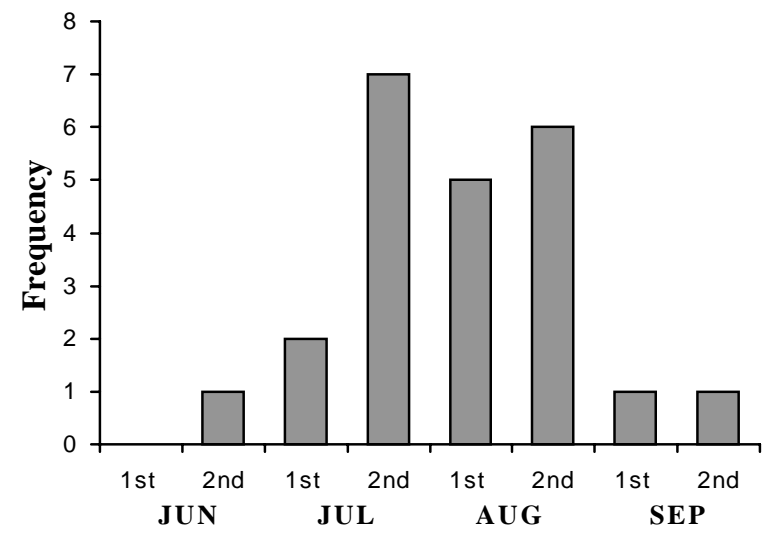

Figure 10

Frequency and periodicity of groups that showed aggression and persecution, displays associated to mating periods.

Frecuencia y periodicidad de los grupos que mostraron agresión y persecución, actividades asociadas a períodos de apareamiento.

Table 4

List of displays and frequency observed during the study (overall $n=252$ groups) and during affiliation (n=12) and disaffiliation $(n=7)$ periods.

Lista de pautas de comportamiento observadas durante el estudio (global n=252 grupos) y durante períodos de afiliación (n=12) y desafiliación ( $\mathrm{n}=7$ ) de individuos a los grupos.

\begin{tabular}{|c|c|c|c|c|c|c|}
\hline \multirow[t]{2}{*}{ DISPLAY } & \multicolumn{2}{|c|}{ OVERALL } & \multicolumn{2}{|c|}{ AFFILIATION } & \multicolumn{2}{|c|}{ DISAFFILIATION } \\
\hline & $\mathrm{n}$ & $\%$ & $\mathrm{n}$ & $\%$ & $\mathrm{n}$ & $\%$ \\
\hline Back or side breach & 96 & 38.1 & 3 & 25.0 & 4 & 57.1 \\
\hline Front breach & 19 & 7.5 & 2 & 16.7 & & \\
\hline Side swimming & 62 & 24.6 & 8 & 66.7 & 3 & 42.9 \\
\hline Belly-up swimming & 13 & 5.2 & 1 & 8.3 & & \\
\hline Tail slap & 45 & 17.9 & 6 & 50.0 & 1 & 14.3 \\
\hline Pectoral slap & 37 & 14.7 & 4 & 33.3 & & \\
\hline Tail slash & 12 & 4.8 & 1 & 8.3 & 2 & 28.6 \\
\hline Logging (motionless at surface) & 15 & 6.0 & & & 1 & 14.3 \\
\hline Aggression, chasing & 23 & 9.1 & 4 & 33.3 & 1 & 14.3 \\
\hline Galloping on the surface & 3 & 1.2 & & & 1 & 14.3 \\
\hline Head out the water & 11 & 4.4 & 1 & 8.3 & & \\
\hline
\end{tabular}




\section{Discussion}

\section{Abundance and seasonally}

The presence of humpback whales off the Ecuadorian coast is clearly a seasonal event with reproductive and calving purposes. The first whales arrive off Ecuador as early as the end of May and the peak of abundance is reached in July. Henceforth, abundance begins a steady decrease as the whales spread out in the whole breeding area, which probably extends at least $1,000 \mathrm{~km}$ along the coasts of Ecuador, Colombia and Panama (Flórez et al. 1998) and perhaps the Galapagos Is. $-1,000 \mathrm{~km}$ west from the Ecuadorian coast- where the species have been occasionally sighted (Day 1994, Merlen 1995). Sightings decline by the end of September and tourist operators report that whales are seen only occasionally around La Plata Island in October. A similar abundance pattern was found by Scheidat et al. (2000) during their study (1996-1999) in the same area off Ecuador. However, at Gorgona Island, Colombia (550km north), the peak of abundance is reported to occur between August and October (Bravo et al. 1994²). Our explanation of such a difference is that whales are not seen in larger numbers earlier at Gorgona because this is a major nursing area (see Flórez 1991 and Ojeda and Hurtado 1992). Whale density along both Ecuadorian and southern Colombian waters is believed to be similar during the whole season, but because births occur in August and September, coastal shallow areas begin to be more frequented by whales for nursing at this time.

Since no second peak of abundance is noticed by the end of the season off Ecuador, Scheidat et al. (2000) suggested that humpback whales off Colombia move toward the west "possibly passing the Galapagos Islands" before their return to the Antarctic. We consider that the absence of such a second peak would be caused merely because the departing period is larger than the arrival period. Nursing lasts at least 2 months beyond whales commencing their southern migration, as suggested by the sightings in November and even on the first days of December at Gorgona Is. (Flórez et al. 1998) and off the northern coast of Peru (Ramírez and Urquizo 1985, Ramírez 1988). Because northward and southward migrations overlap at breeding grounds (Dawbin 1966), it is not possible to know with certainly when the different age-classes start leaving. One could expect a weak (as seen in Puerto Cayo) or no second

\footnotetext{
2 Bravo GA, L Flórez \& J Capella. 1994. Natalidad y frecuencia estacional de crías de ballena jorobada, Megaptera novaeangliae, en el Pacífico colombiano. Anais da 6a Reuniao da Trabalho de Especialistas em Mamíferos Aquáticos da América do Sul. Florianópolis, Brasil. 24-28 de Outubro de 1994, p. 76. (Abstract).
}

peak at all if the whales leave the breeding area gradually. Also, because mother with calf is the last departing class (Dawbin 1966), whales at the end of the season would be found mainly along shallow zones (see bellow), which explains the drop of sightings around La Plata Island in October.

\section{Sighting distribution}

GPS-positioned sightings indicate that whales did not distribute uniformly inside the study area, but they tended to concentrate their activities at specific sites. Around La Plata Is. and at Bajo de Cantagallo whales formed bigger groups composed mainly of adult and subadult animals. In contrast, nearby Puerto Cayo, groups were smaller and formed mainly by mothers with calves and solitary individuals (see Figs 5 and 8). For mothers and calves, water depth was a major factor affecting their distribution, they preferred shallow waters of 20m or less in depth. Flórez (1991) and Ojeda and Hurtado (1992) also reported that mother and calves were mainly observed in shallow waters on the East Side of Gorgona Island. These places would be chosen because they offer a better protection from deep-water predators such as killer whales and big sharks. A clumped distribution and concentration of mother with calves in shallow waters have been also reported in Hawaiian humpback whales during the breeding season (Herman and Antinoja 1977, Darling et al. 1983, Mobley and Herman 1985).

\section{Birth rate}

Spatial segregation of mothers with calves also explains the differences in the crude birth rate found in both routes, with the shallower Puerto Cayo's showing the highest value (see Table 3 ). The average crude birth rate for the study area (0.039) is 3 times lower than those observed at Gorgona Is. (0.17) (Bravo et al. $1994^{2}$ ) and is one of the lowest reported for any humpback whale stock (see Best 1993). The absence of trips during October, when mothers with calves are still in the area and its proportion as class would be higher because most of the animals moved to the Antarctic earlier, contributed to the low estimation of this parameter. To obtain a more realistic estimation of the reproductive capacity of the species it is necessary to take into account the biases caused by the segregation of females with calves, the lateness of the parturition and the prolonged nursing period.

\section{Group structure and behavior}

Larger groups were found in July and August in both routes, coinciding with the major abundance of whales in the study area and with the highest level of activity. Large groups would be formed by adult males (escorts) in pursuit of a receptive female. Both ovulation and spermatogenesis peak between the later part of July and 
early August in southern humpback whales (Chittleborough 1955, 1958). Tyack and Whitehead (1983) and Baker and Herman (1984) found a structured order among these competing males in northern populations, but this could not be established in our study likely because the shorter observation period (mean=33.4 minutes). Baker and Herman (1984) also reported a relationship among the abundance peak, group size and the increase of aggressiveness in Hawaiian humpback whales. Differing from Puerto López, Puerto Cayo's groups increased its size at the end of the season again, although not to the level found in August. This difference could be related to the presence of more females with calves at Puerto Cayo, which explains also the second peak of abundance in September (see fig. 3). Scheidat et al. (2000) also found an increase in group size and surface activity with the season around La Plata Is.. Tyack and Whitehead (1983) informed that larger groups were found at the end of the breeding season in the Antilles and Herman and Antinoja (1977) and Darling et al. (1983) reported that mother and calves are more often found with other adult animals at the end of the season also in Hawaii. Females with calves would become an attraction nucleus for other whales, both females performing allomaternal behavior and males attracted by a postpartum ovulation join female-calf pairs at this part of the season providing additional protection to calves (Herman and Tavolga 1980).

Whale groups in the study area seemed not to maintain long-lasting associations among individuals. They changed at least one member on average every 254 minutes, except when they contained a mother-calf pair. Temporal associations with great fluidity of individuals seems to be common to humpback whales both at breeding grounds (Darling et al. 1983, Mobley and Herman 1985, Tyack and Whitehead 1983) and at feeding grounds (Whitehead 1983). Changes in membership could be related in many cases to male competition for access to receptive females. But in nonreproductive groups other subtle aspects of whale sociality such as kinship, age-class alliances, etc., would be responsible for the compatibility among individuals. Our data indicate that surface activity increases during periods of change in membership and that specific behaviors are displayed either if affiliation or disaffiliation occurs (see Table 4). A deeper analysis of whale behavior during such periods could help to understand better their social structure.

\section{Site Fidelity}

The low number of resightings even during the same season suggests that whales did not stay for long in the same area. Scheidat et al. (2000) also reported that only $10 \%$ of the whales spent more than two weeks around.
A similar conclusion arrived researchers working in northern populations (e.g. Darling et al. 1983, Herman and Antinoja 1983, Whitehead 1983, Mobley and Herman 1985). However, Colombian whales breeding at Gorgona Is. showed an unusually high level of residence and site fidelity; whales remained around 17 days on the average (Capella et al. $1995^{3}$ ) and the annual return of individuals was between 13 and 22\% in the period 1986-1991 (Flórez 1992 ${ }^{4}$ ). A possible explanation of these differences in respect to Ecuadorian whales could be that a high proportion of whales frequenting the study area off Ecuador are animals in transit. Although few, interannual resightings showing annual synchrony suggests a cyclic rather a resident use of the area by some whales. Another possible explanation is that, despite their proximity, the age-sex class composition is different in both sites. At Gorgona Is. up to $50 \%$ of recorded whales are mothers and calves (Flórez 1991) compared to less than 10\% found in our study area. Because mother with calf distribution is limited to shallow zones, their level of residence and fidelity would be higher than other classes. Both theories are also supported by the low rate of common individuals observed when a comparison of photo-identified whales from La Plata Is. and Gorgona Is. was made in an early part of this study (Flórez et al. 1998, Muñoz et al. $1998^{1}$ ).

\section{Population size}

Several population estimates have been made recently at Colombia and Ecuador using mainly mark-recapture methods. Flórez (1991) estimated on 170-450 and Ojeda and Hurtado (1995) on 127-645 individuals the number of whales at Gorgona Island. A previous estimate made in Ecuador sized the southeastern Pacific stock to be between 994 and 1,698 animals (Haase 1990). Scheidat et al. (2000) estimated on 405 animals (95\% CI 221-531) the population in our study area in 1998. The lower estimates obtained at Gorgona can be explained also because the group composition is different in both sites. But in the case of the two estimates on the Ecuadorian coast other factors are probably involved. Our estimate resulted more

\footnotetext{
${ }^{3}$ Capella J, L Flórez \& GA Bravo. 1995. Site fidelity and seasonal residence of humpback whales around isla Gorgona, a breeding ground in the Colombian Pacific. Eleventh Biennial Conference on the Biology of Marine Mammals, 14-18 December 1995. Orlando, USA, p. 20. (Abstract).

${ }^{4}$ Flórez L. 1992. Filopatria reproductiva y tendencia grupal de yubartas en el Pacífico colombiano. Resúmenes de la $5^{\text {ta }}$ Reunión de Especialistas en mamíferos Acuáticos de América del Sur, 28de septiembre-2 de Octubre 1992, Buenos Aires, Argentina. p. 26. (Abstract).
} 
concordant to Haase's, despite the different method he used (direct counts from land and sea), than with Scheidat et al. (2000) who used a mar-recapture estimator with photo-identified animals. A more exhaustive discussion on the methodology used and the possible sources of bias is available elsewhere (Félix and Haase, in press). Notwithstanding its wide confidence interval, the estimate here presented (1,922 whales, 95\% C.I. 77-3,367) provides a clue about the current number of humpback whales in the southeastern Pacific stock. However, we recognize that the estimate is based on limited data.

\section{Acknowledgements}

We would like to thank all FEMM volunteers and coworkers who helped us as field assistants during the trips. The directors and crew of the agencies Mantaraya, Whale Tours and Galamazonas, who kindly allowed us on board of their boats to do the research. Two anonymous reviewers made valuable comments to improve this article. We are grateful to Mr Sean Whyte for believing in our project and for his permanent support and friendship. We thank to the Whale and Dolphin Conservation Society (WDCS), Bath, England, and especially to its Conservation Director Alison Smith, for the financial support to our research.

\section{Literature cited}

Aguayo A. 1974. Baleen whales off continental Chile. p. 209217. In: W. E. Schevill (Ed.). The Whale Problem, a Status Report. Harvard University Press. Cambridge, Mass., U.S.A.

Baker CS \& LM Herman. 1984. Aggressive behavior between humpback whales (Megaptera novaeangliae) wintering in Hawaiian waters. Canadian Journal of Zoology 62: 1922-1937.

Best PB. 1993. Increase rates in severely depleted stocks of baleen whales. ICES Journal of Marine Science 50: 169-186.

Caballero S, H Hamilton, L Flórez, J Capella, C Olavarría, HC Rosenbaum \& CS Baker. 2000. Stock identity and diversity of humpback whale mitochondrial DNA lineages on the Colombian winter breeding grounds. Paper SC/52/IA14, presented to the $52^{\text {nd }}$ Scientific Committee of the International Whaling Commission at Adelaide, Australia. June 2000.

Capella J \& L Flórez. 1993. Tras el rastro de la ballena jorobada. Boletín Antártico Chileno 12(1): 2-4.

Chapman DG. 1974. Status of the Antarctic rorqual stocks. p. 218-238. In: W. E. Schevill (Ed.). The Whale Problem, a Status Report. Harvard University Press. Cambridge, Mass., U.S.A.
Chiriboga HA. 1972. Las Ballenas en el Pacífico Sur Oriental. Instituto Oceanográfico de la Armada del Ecuador, Salinas, Ecuador. 54 p.

Chittleborough RG. 1955. Aspects of reproduction in the male humpback whale, Megaptera nodosa (Bonnaterre). Australian Journal of Marine and Freshwater Research 6: 1-29.

Chittleborough RG. 1958. The breeding cycle of the female humpback whale, Megaptera nodosa (Bonnaterre). Australian Journal of Marine and Freshwater Research 9: $1-18$.

Clarke R. 1962. Whale observation and whale marking off the coast of Chile in 1958 and from Ecuador toward and beyond the Galapagos Islands in 1959. Norsk HvalfangstTidente 7: 265-287.

Clarke R. 1980. Catches of sperm whales and whalebone whales in the Southeast Pacific between 1908 and 1975. Report of the International Whaling Commission 30: 285-288.

Clarke R. 1992. Las investigaciones balleneras en el Pacífico Sureste. Memoria X Congreso Nacional de Biología, Agosto 2-7 de 1992. Lima, Perú, p. 79-90.

Espinoza J. 1996. El Niño y sus implicaciones sobre el medio ambiente. Acta Oceanográfica del Pacífico 8(1): $115-134$.

Darling JD, KM Gibson \& GK Silber. 1983. Observations on the abundance and behavior of humpback whales (Megaptera novaeangliae) off West Maui, Hawaii, 19771979. In: R. Payne (Ed.). Communication and Behavior of Whales. AAAS Selected Symposia Series, Westview Press, Boulder CO. p. 201-222.

Dawbin WH. 1966. The seasonal migratory cycle of humpback whales. p. 145-170. In: Norris K.S. (Ed.). Whales, Dolphins and Porpoises. Univ. California Press. Berkeley, CA. 789 p.

Day D. 1994. List of cetaceans seen in Galápagos. Noticias de Galápagos 53: 5-6.

Félix F \& B Haase. 1996. Humpback whale research in Ecuador in 1996. Report to Whale and Dolphin Conservation Society, Bath, England. 26 p +2 Appendix. [Unpublished].

Félix F \& B Haase. 1997. Research on humpback whale along the Ecuadorian coast in 1997. Report to the Whale and Dolphin Conservation Society, Bath, England. 33 p. [Unpublished].

Félix F \& B Haase. 1998. La investigación de la ballena jorobada (Megaptera novaeangliae) alrededor de la isla de La Plata, Manabí, durante 1995. Acta Oceanográfica del Pacífico 9(1): 219-227.

Félix F \& B Haase. (In press). Towards an estimate of the Southeastern Pacific humpback whale stock. Journal of Cetacean Research and Management.Vol. 3. 
Flórez L. 1991. Humpback whales Megaptera novaeangliae in the Gorgona Island, Colombian Pacific breeding waters: population and pod characteristics. Memoirs of the Queensland Museum 30: 291-295.

Flórez L, J Capella \& HC Rosenbaum. 1994. Attack of killer whales (Orcinus orca) on humpback whales (Megaptera novaeangliae) on a South American Pacific breeding ground. Marine Mammal Science 10(2): 218222.

Flórez L, J Capella, B Haase, GA Bravo, F Félix \& T Gerrodette. 1998. Changes in winter destinations and the northernmost record of southeastern Pacific humpback whales. Marine Mammal Science 14(1): 189-196.

Haase B. 1990. Study of the humpback whale Megaptera novaeangliae in Ecuador, with an estimation of the eastern tropical Pacific stock boundaries. Progress Report to Whale and Dolphin Conservation Society, Bath, England. 11 p. [Unpublished].

Hammond PS. 1986. Estimating the size of naturally marked whale populations using capture-recapture techniques. Report of the International Whaling Commission (special issue 8) 253-281.

Herman LM \& RC Antinoja. 1977. Humpback whales in the Hawaiian breeding waters: population and pod characteristics. The Scientific Reports of the Whales Research Institute 29: 59-85.

Herman LM \& WN Tavolga. 1980. The communication system of Cetaceans. Pp. 149-209. In: Lois M. Herman (Ed.), Cetacean Behavior, Mechanisms and Functions. John Willey \& Sons, New York. 463 p.

Jefferson TA, S Leatherwood \& MA Webber. 1993. FAO species identification guide. Marine Mammals of the world. Rome. 320 p.

Katona S, B Baxter, O Brazier, S Kraus, J Perkins \& H Whitehead. 1979. Identification of humpback whales by fluke photographs. Pp. 33-34. In: H.E. Winn and B.L. Olla (Eds.). Behavior of Marine Animals Vol. 4. Plenum Press.

Leatherwood S \& RR Reeves. 1983. The Sierra Club Handbook of Whales and Dolphins. Sierra Club Books. San Francisco. 302 p.

Merlen G. 1995. A Field guide to the Marine Mammals of Galapagos. Instituto Nacional de Pesca, Guayaquil, Ecuador. 130 p.
Mobley JR Jr \& LM Herman. 1985. Transience of social affiliations among humpback whales (Megaptera novaeangliae) on the Hawaiian wintering grounds. Canadian Journal of Zoology 63: 762-772.

Ojeda ZV \& LA Hurtado. 1992. Aspectos biológicos de la yubarta Megaptera novaeangliae durante su ciclo reproductivo en la isla Gorgona, 1991. Memorias del VIII Seminario de Ciencias y Tecnologias del Mar y Congreso Centroamericano y del Caribe de Ciencias del Mar. Santa Marta. Colombia. p. 697-708.

Ramírez P. 1988. La ballena jorobada Megaptera novaeangliae en la costa Norte del Perú. Boletín de Lima 56: 91-96.

Ramírez P \& W Urquizo. 1985. Los cetáceos mayores y el fenómeno "El Niño" 1982-1983. p. 201-206. In: W. Antz, A. Landa y J. Tarazona (Eds.). "El Niño” Su Impacto en La Fauna Marina. IX Congreso Latinoamericano de Zoología. Arequipa, Perú, 9-15 de octubre 1983.

Reeves RR \& S Leatherwood. 1994. Dolphins, Porpoises and Whales: 1994-1998 Action Plan for the Conservation of Cetaceans. IUCN, Gland, Switzerland. 92 p.

Scheidat M, C Castro, J Denkinger, J González \& D Adelung. 2000. A breeding area for humpback whales (Megaptera novaeangliae) off Ecuador. Journal of Cetacean Research and Management 2(3): 165-171.

Seber GAF. 1982. The Estimation of Animal Abundance and Related Parameters. Griffin, London. 654 p.

Silber GK. 1986. The relationship of social vocalizations to surface behavior and aggression in the Hawaiian humpback whale (Megaptera novaeangliae). Canadian Journal of Zoology 64: 2075-2080.

Stone GS, L Flórez \& S Katona. 1990. Whale migration record. Nature, Lond. 346: 705.

Townsend CH. 1935. The distribution of certain whales as shown by the logbook records of American whaleships. Zoologica NY 16: 133-144.

Tyack $\mathbf{P}$ \& $\mathbf{H}$ Whitehead. 1983. Male competition in large groups of wintering humpback whales. Behaviour 83: $132-154$.

Whitehead H. 1983. Structure and stability of humpback whale groups off Newfoundland. Canadian Journal of Zoology 61: 1391-1397. 